European journal of American studies

Special Issue: Media Agoras: Islamophobia and Inter/ Multimedial Dissensus

\title{
Challenging Islamophobia through Intermediality: Anida Yoeu Ali's Performance Art
}

Martina Pfeiler

\section{(2) OpenEdition}

\section{Journals}

Electronic version

URL: https://journals.openedition.org/ejas/16298

DOI: $10.4000 /$ ejas. 16298

ISSN: 1991-9336

Publisher

European Association for American Studies

Electronic reference

Martina Pfeiler, "Challenging Islamophobia through Intermediality: Anida Yoeu Ali's Performance Art", European journal of American studies [Online], 15-3 | 2020, Online since 01 October 2020, connection on 08 July 2021. URL: http://journals.openedition.org/ejas/16298 ; DOI: https://doi.org/10.4000/ejas. 16298

This text was automatically generated on 8 July 2021.

Creative Commons License 


\title{
Challenging Islamophobia through Intermediality: Anida Yoeu Ali's Performance Art
}

\author{
Martina Pfeiler
}

\section{Introduction}

1 Within the framework of American Studies, Anida Yoeu Ali's work is of immediate relevance as it embodies a feminist, transnational critique of an unprecedented "undermining [of] Muslim voices" (Azam 125). Her performance art not only deals with the impact of the aftermath of $9 / 11$ on Muslim Americans. It is also relevant to a globally growing Black Lives Matter movement in view of Donald Trump's presidency that has curtailed the rights of ethnic Others and thus participates in acts of racism. Keeanga-Yamahtta Taylor highlights systemic racism within the current U.S. government as follows:

Republicans, led by Trump, have referred to Black activists as 'identity extremists' and they have referred to the Black Lives Matter movement as 'terrorist,' while simultaneously minimizing, if not ignoring, the President's repeated sympathetic gestures towards racists who espouse hate speech towards African Americans, Muslims, Mexicans, Puerto Ricans, and other victims of racial and ethnic discrimination. (103)

In view of these alarming realities for ethnic minorities, this article investigates Anida Yoeu Ali's performance art as that of a Muslim, Khmer-American feminist global agitator. As I suggest, Ali challenges Islamophobia in the United States and transnationally by expanding her work "into ever-widening arenas" (Fraser, Justice Interruptus 82). Ali confronts America's frequent monolithic representations of Muslim American identities in mainstream media. And, in doing so, she is creating counterdiscourses that formulate oppositional interpretations of Muslim "identities, interests, and needs" (Fraser, Justice Interruptus 82). Drawing on theories of convergence culture and intermediality, this article closely analyzes Ali's performance projects in 
terms of how they challenge Islamophobia in today's digitized, transnational, and intersectional world: The first example is titled 1700\% Project: Mistaken for Muslim (2010), a performance poetry clip that was directed by the Japanese American filmmaker Masahiro Sugano and which widely circulates on various platforms such as YouTube and Vimeo on the Internet. The article also includes an exploration of a selection of performance acts from The Red Chador Series (2015; 2018; 2020). I argue that by establishing discursive counternarratives the two works highlight the cultural potential of using intermediality to challenge private and public Islamophobia in a globally connected world. Thus, these works will be explored as a performative engagement with national, transnational, and gendered dimensions of Islamophobia.

\section{Islamophobia and Intermediality in the Context of Twenty-First Century Convergence Cultures}

3 According to Khaled Beydoun, the term Islamophobia cannot be considered without its dialectical dimension, i.e. "the ongoing dialogue between state and citizens" (29). Among other things, new social media networks and a changing national and transnational media landscape have accelerated this dialogue, which is not without bigotry, racism and hatred against marginalized peoples.

4 These mediatized forms of hate speech include Islamophobic statements by politicians, for instance on Twitter, where they are subsequently commented on, contested, or supported by followers. Donald Trump's preelection statement "I think Islam hates us" (09:35-09:37) in an interview with Anderson Cooper on CNN on March 10, 2016, which was also posted on the Internet, serves as just one flagrant example of how influential politicians with a wide media reach not only create but reinforce a hegemonic white supremacist viewpoint. In fact, Trump strategically constructs Islam as a threat to U.S. value systems. The overall effect with regard to the representation of Muslim identities in digital media, as coming from the President of the United States, is one that continues to reinforce a white, hegemonic U.S. American society that is molding public and private images of ethnically marked Muslims as the Other.

5 In order to assess this profound cultural shift of creating new audiences and new media cultures on the Internet, it is helpful to briefly turn to Henry Jenkins's essay "The Cultural Logic of Media Convergence" from 2004, in which he states:

[m] edia convergence is more than simply a technological shift. Convergence alters the relationship between existing technologies, industries, markets, genres and audiences. Convergence refers to a process, but not an endpoint. Thanks to the proliferation of channels and the portability of new computing and telecommunications technologies, we are entering an era where media will be everywhere and we will use all kinds of media in relation to each other. (36; emphasis added)

6 Put simply, new audiences and genres not only emerge but also converge and thus put media, and the content of media, in relation with each other. This change is facilitated by technical appliances such as through the use of smartphones, digital cameras, and laptops, etc. in the production and distribution process, generating new media cultures. Equally relevant, Jens Schröter's useful categorization for intermediality as a result of the shift from analogue to digital, foregrounds the question of media archeologies that rely on analogue and digital technologies, or both. Schröter differentiates between 
synthetic intermediality (i.e. art happening), transmedia intermediality (i.e. computer simulation), transformational/ontological intermediality (i.e. remediating a medium through another medium). The last two categories, according to Schröter, involve digital media (Schröter 579-601). While this overview of various operational dimensions of intermediality highlights the forms and technical applications, all of which play an important role in Ali's work, an additional focus on the discursive strategies of intermediality bears significance. Drawing on Klaus Bruhn Jensen's definition of intermediality, the term "denotes communication through several discourses at once, including through combinations of different sensory modalities of interaction, for instance music and moving images" ( 1 ; my emphasis).

8 Thus, I would like to investigate the discursively mediated strategies that are involved in challenging Islamophobia through intermedia art and convergence media. The first aspect draws on the use of the term Islamophobia itself, which according to Steven George Salaita's article "Beyond Orientalism and Islamophobia: 9/11, Anti-Arab Racism, and the Mythos of National Pride" (2006) requires a more transparent geopolitical focus. He prefers the term Anti-Arab racism, suggesting that "Islamophobia... has ambiguities that limit its clarity" (249). Salaita adds: "Not all victims of Islamophobia are Muslim, and while fear of Muslims, as the word's suffix implies, certainly inspires hatred of them in some cases, we must take much more into account historically in order to accurately delineate a context for the hatred" (249).

At the core of his critical reflection lies the risk of homogenizing all forms of Islamophobia, which requires a nuanced historical articulation of the cultural contexts in which Islamophobia occurs. Salaita considers the term Anti-Arab racism as a "more accurate replacement for the traditional descriptors Orientalism and Islamophobia in relation to the negative portrayal of Arabs in the United States" (245). Yet, I will stick to the term Islamophobia precisely because of the ambiguity it raises in Anida Yoeu Ali's art. In light of the global outreach of her performance art, her work complicates the boundaries of a "transnational transposition of a large variety of Islamic practices" (Mas 125).

Secondly, when investigating representations of Muslim identities, an intersectional approach is key. Ali situates herself within a "gendered side of Islamophobia" (Jamal 472). Amaney A. Jamal views the aspect of gender as follows: "Chief among the targets of this Islamophobic tide are Muslim women identifiable to the public as Muslims because they wear hijabs. Muslim women have seen hate crimes against them escalate since the electoral campaign and election of Donald Trump" (472). Thus, it becomes clear that Islamic feminism, just like Islamophobia, cannot be generalized as one monolithic, ideological global fight by Muslim women. In the strategic fight against discrimination, racial signifiers put Muslim women at a higher risk. This is particularly noteworthy in a U.S. context, where Islamophobia clashes with "the Constitution's protection of religious freedom" (Feldman 142). Thus, the question of how to counter Islamophobia involves Muslim women's decision of wearing, or not wearing, the hijab as an integrative part of the feminist Islamic protest. From a Muslim perspective, this runs deeper in view of attacks on Muslim women as "women" and as "Muslim," who are immediately seen as oppressed and forced into veiling. Indisputably, this stereotypification disregards a deeply rooted theological Muslim feminism that seeks to reconcile gender equality based on a feminist reading of the Qu'ran (Hassan 87). 
11 Given that these intersectional issues frequently arise from structural, private, and gendered Islamophobia within and beyond the United States, I would like to explore in the remainder of this article how Anida Yoeu Ali's multifaceted performance art intermedially challenges Islamophobia.

\section{Islamophobia and Intermediality in $1700 \%$ Project: Mistaken for Muslim}

12 Anida Yoeu Ali is a first generation Cambodian American artist, who grew up in a Muslim community in Battambang, Cambodia. At a young age she fled with her family from the Khmer Rouge regime in 1979, forcing them to restart their life in Chicago in the early 1980s (Schlund-Vilas 58). As a nationally emerging spoken word poet and performance artist, Ali studied graphic design at the University of Illinois and completed an M.F.A. at the Art Institute of Chicago. In 2011 she left for Cambodia on a Fulbright, where she pursued her art in collaboration with the Japanese American filmmaker and partner Masahiro Sugano. Together they founded the collaborative multimedia lab Studio Revolt, producing performance poetry clips and the awardwinning documentary Cambodian Son (2014). It features the exiled Khmer American spoken word artist Kosal Khiev and his exceptional life journey from refugee to prisoner to poet and selected representative of Cambodia at the 2012 Cultural Olympiad in London.

In 2016 Ali accepted a teaching position at Trinity College at Hartford, Connecticut. Today she teaches at Bothell University, where she is a Senior-Artist-in-Residence, "whose works span performance, installation, video, images, public encounters, and political agitation" (Bothell U bio; Web). Her performance art has received international recognition by winning the Sovereign Asian Art Prize in 2015, "the most established and prestigious annual art award in Asia-Pacific" (Web). Ali has also received grants from the Rockefeller Foundation and the National Endowment of the Arts, and, more recently, she was invited to a Global Salzburg Seminar titled "The Art of Resilience: Creativity, Courage and Renewal" (Abellan 2017).

Anida Yoeu Ali's 5-minute color performance poetry clip, 1700\% Project: Mistaken for Muslim, was directed by Masahiro Sugano in 2010. As a product of media convergence, not only the digital camera work, but also various editing decisions made by the filmmaker via computer software and adding sound layers play a crucial role in the overall film-poetic concept.

15 Although I will focus on the clip in my analysis, the poem originated as part of an installation project titled Otherance (2010) by Ali in the Sullivan Galleries at the School of the Art Institute in Chicago. Next to a polyvocal performance of the poem, the installation included a wall art piece that, according to Ali, ended up being vandalized. In response to the vandalism Ali invited the larger community into the performance space to raise awareness and psychologically process the hate crime (Schlund-Vials 64). This aspect is crucial to mention as the stylized performance clip that followed the installation is also decidedly community-based.

16 Verbally, the spoken word poem is constructed as a cento, which translates from Latin as patchwork. Traditionally, a cento is a "verse composition made up of lines selected from the work or works of some great poet(s) of the past" (Preminger 180). In fact, its 
tradition reaches back to Greek and Latin literature. It regained popularity in Renaissance literature such as in "the Engl[ish] Cicero Princeps (1608), which was a treatise on government compiled from Cicero" (ibid.). As the New Princeton Encyclopedia of Poetry and Poetics further states, today they are "almost invariably humorous, the humor arising from both the clever juxtaposition of famous lines into a new semantic matrix and also recognition of the diversity of their sources" (180). In Ali's case, the cento is based on a series of "[f]iled hate crime reports on people who were perceived to be Muslims or Muslim" (Project Website).

As Schlund-Vilas states, the poem includes "excerpts from Federal Bureau of Investigation and police reports filed by South Asian American, Arab American, and Muslim American victims of hate crime violence" (63). Ali embeds these state reports about Islamophobic hate crimes in the cento tradition. Rather than staying factual about them, she uses irony to the effect of exposing the absurdity of the racially motivated hate crimes. Thus, she reframes these statements in the form of a mash-up and reconstructs them to not only expose Islamophobia in the United States but to formulate a counternarrative with them. As I would like to suggest, the postmodern performance poetry clip follows the cento tradition not only verbally, but also in the form of its diverse visual ethnic representation of more than one-hundred community members from the Chicago area. Each one of the participants counters "monolithic stereotypes of a 'Muslim' identity while acknowledging the significance of historical persecution" (Web).

Turning to the performance poem itself, its verbal dimension is inextricably intertwined with these visual shots as well as extradiegetic sounds. As an intermedia art form, the result is a performance poetry clip, in which sound layers and visuals may be added as part of a concept video featuring a poet performing his or her work in front of a camera (Pfeiler 172-176). Although the spoken word poem is the genre-defining element of the digital clip at hand, media play a decisive role in its multi-layered, discursive construction.

Already within the first few seconds of the clip "several discourses merge at once" (Jensen 1). In effect, this comes from a "combination of different sensory modalities of interaction" (Jensen 1), in this case from sound and moving images. Synchronous to its symbolic establishing shot in the outskirts of Chicago, one hears a polyphonic sound collage of several male and female Anglophone American voices. In this chaotic soundscape, fragmented commentaries stand out audibly, most notably about New York's Major Giuliani and President Bush's response after the attacks on the Twin Towers (0:00-0:27). Evocative of a conspiracy theory in its lowered tone, one hears a piece of advice as voiced by a male speaker to not only stay "conscious" (0:05), but "to remain critical of this government" (0:07-0:08).

In fact, a potential danger coming from the U.S. government itself in the aftermath of the $9 / 11$ terror attacks is made clear by way of an epigraph on a black intertitle with white font. This epigraph draws an immediate connection to acts of state-based racism. It reads: "February 12, 1942. Executive Order 9066 authorized to U.S. military to incarcerate 112,000 Japanese Americans into ten internment camps" (0:07-0:12).

21 With these written lines, the rhythmic beat continues and just less than two seconds before cutting to a second epigraph, one receives a bird's-eye glimpse of several superimposed shots of contemporary Khmer dancer Prumsodon Ok (0:41-0:44): 


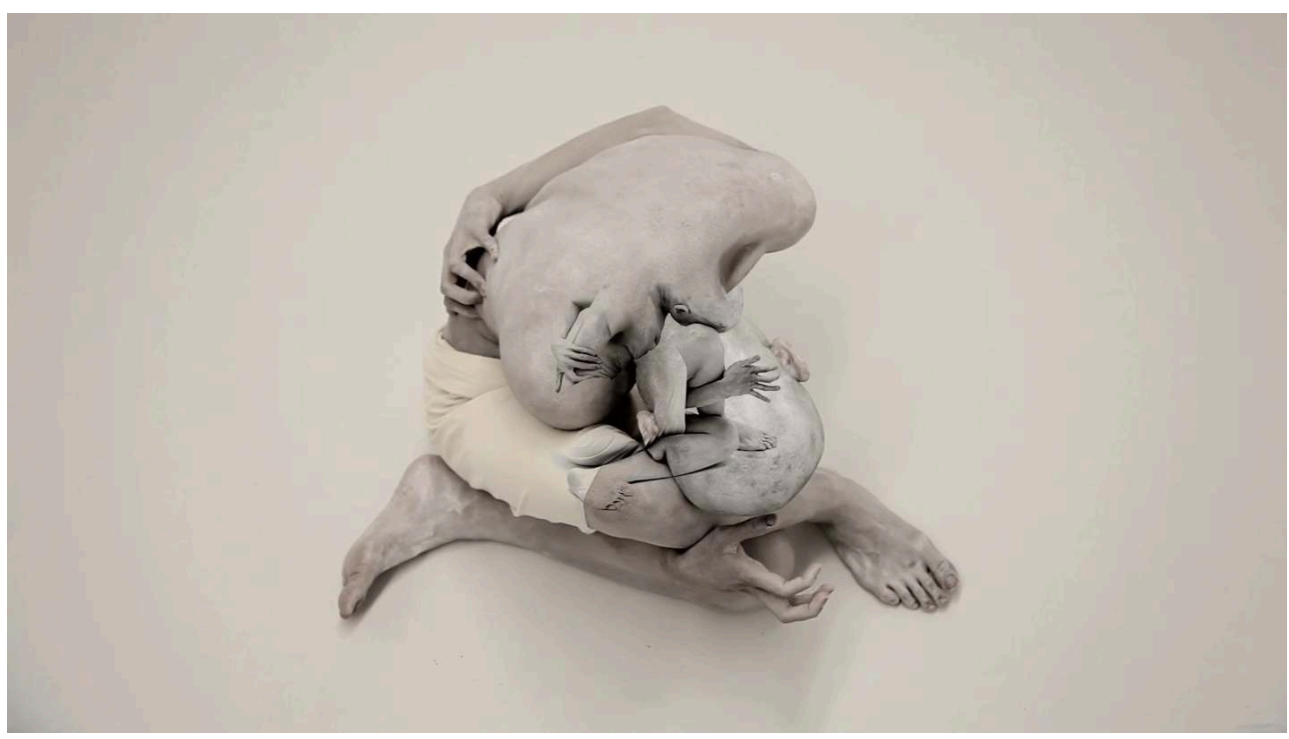

Fig. 1 Prumsodon Ok in 1700\% Project: Mistaken for Muslim. Photo Credit: Masahiro Sugano.

In this scene, the viewer's gaze is drawn into the superimposed, visual representation of Ok's severed body, which is wrapped in a white cloth around his loins. As the image conveys, he is reaching for his back with one arm in a cramped pose, while being couched in a fetal position attempting to protect his head. In effect, this not only expresses vulnerability, but the white chalk on his skin symbolically suggests oppression by white supremacy, i not internalized racism.

A hard cut to a second epigraph reads: "March 28, 2003. Following the events of 9/11, the FBI created an Arab American Advisory Committee after hate crimes against people perceived to be 'Arab' or 'Muslim' increased by 1700\%" (0:15-0:23). And while a historical comparison would be uneven, the epigraph highlights that xenophobia against Muslim Americans is not only at a record high, but it could potentially reverse to the extent that Japanese Americans had to endure it in the 1940s. Thus, the first epigraph exposes the reality of America's historical connection with racist political agendas as a nation, while the second epigraph serves to highlight the alarming degree of private Islamophobia in the United States.

These introductory, politicized scenes set the tone for the performance poet's first appearance in the clip. The viewer is confronted with a fade-cut to Ali's body filmed in a high angle shot. She is laying on the ground in open daylight to evoke a burial, with plain earth being removed from the artist's body by way of a stop-motion technique. In effect, the scene alludes to the Khmer background of the artist in a powerful visual statement. In this scene, Ali wears an orange dress that evokes a Buddhist robe, which links itself to the long historical period of Theravada Buddhism in Cambodia. As Richard F. Gombrich explains: "In Cambodia... the Khmer Rouge government of Pol Rot in the late 1970s massacred most of the monks and defrocked the rest" (2). It becomes immediately clear that the burial scene symbolizes the historical dimension of genocide as connected to the Buddhist past. Therefore, these visuals make a strong point about religion as a high-risk factor for people to become victims of oppression and violence to the extent of their elimination. 
Subsequent to the title "1700\% Project: Mistaken for Muslim," the shot fades out to a scene which captures Ali in a rotated eye-level shot, staring upside down at the viewer:

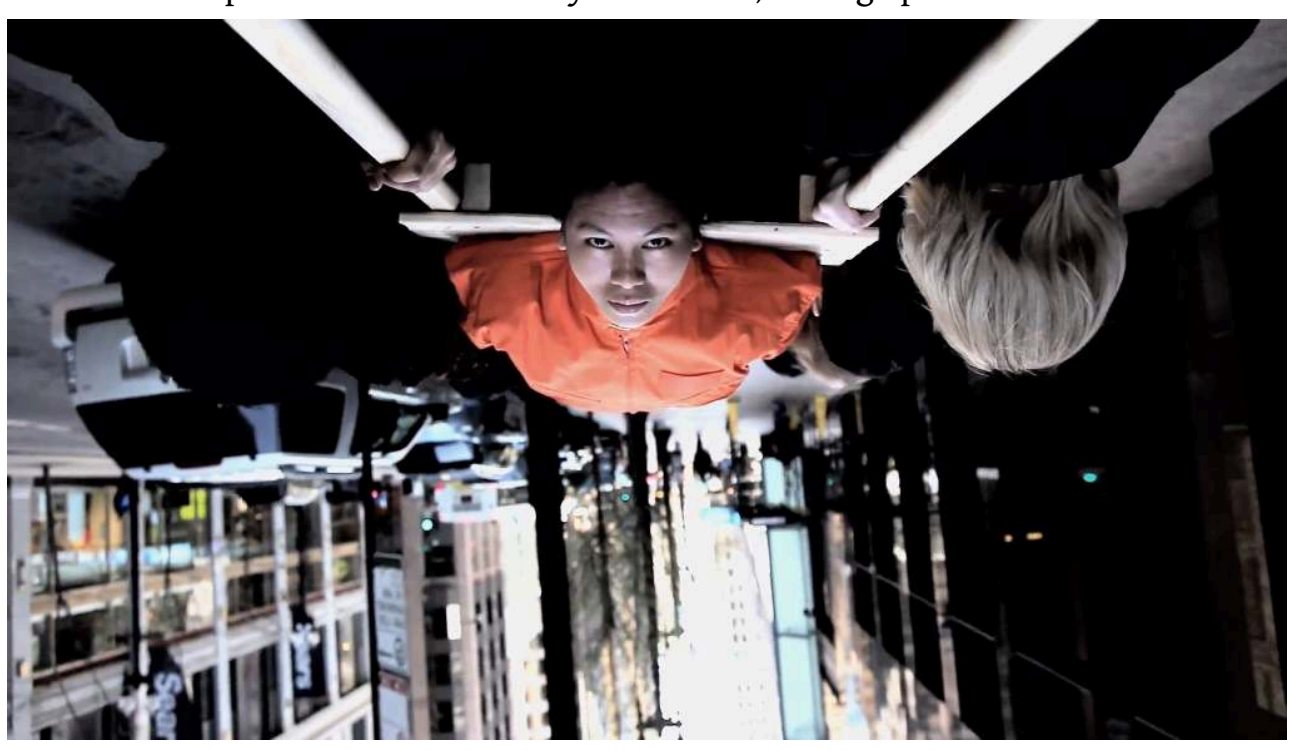

Fig. 2 Anida Yoeu Ali carried through metropolitan Chicago on a snatcher. Photo courtesy of the artist; Photo Credit: Masahiro Sugano.

It is crucial to note here that the image above requires a different reading of the orange robe: within this new urban context, Ali has changed her clothes from a Buddhist robe into a prison jumpsuit. As well known, the latter is used by the U.S. government for non-compliant Guantánamo detainees as a tool of control (Van Veeren 125). In fact, in this associative transformation from the burial of the Buddhist to the rebirthing of a Muslim Guantánamo prisoner, Ali begins her spoken word recitation as follows:

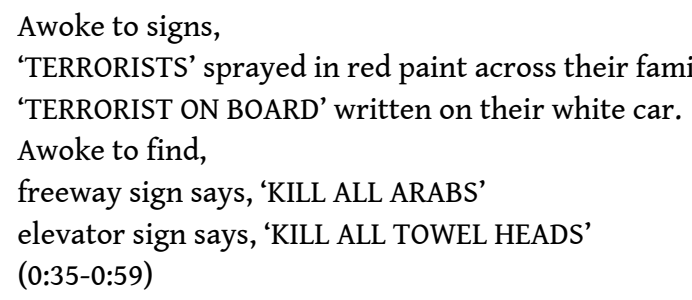

By listing one instance of Islamophobic hate crime after another, Ali's Guantánamo prison persona calls out violence against Muslims, ranging from verbal assault and vandalism to brutal murder to expose the connection between systemic and private racism. For instance, she enumerates the fate of "[a] Pakistani living in L.A." (1:00-1:02), whose "car is scratched along the right side with the words 'NUKE 'EM!" (01:03-1:08). She also calls awareness to an "Egyptian American, 48, killed point-blank" (2:34-2:27), "a South Asian American, Sikh, chased by a group of four men yelling 'TERRORIST"' (01:46-1:53), a "Muslim student at Arizona State University attacked" (3:26-03:28) and "[t]wo women at a bagel store, attacked for wearing a Quranic charm around her [sic] neck" (3:40-3:32). This long enumeration shows that these incidents are not isolated cases. Rather, the selection of quotes from several states in America reveals that Islamophobic racism is an all-pervasive phenomenon. With the exception of two incidents, these reports do not mention whether the perpetrators are white. Thus, it also becomes clear that these FBI reports shift the focus on the victims, rather than dealing with the actual source of the Islamophobic hate-crime. 

addition to four dark-hooded people who are shouldering the prisoner on a stretcher through a commercial district of metropolitan Chicago. As I would like to suggest, this rotated scene draws on Middle Eastern funeral scenes, in which the corpse is wrapped in shrouds and carried by mourners through streets on a stretcher. Thus, they allude to the aftermath of terror on Muslim people via airstrikes and, simultaneously, place the stylized audiovisual image of a Muslim victim directly on U.S. soil. In effect, these scenes intermedially express an awareness of a multilayered geopolitical context, in which the United States are inextricably linked to the killing of people in the Middle East.

Ali's agitated voice humanizes the factual FBI reports. While the spoken word poem is persuasive by itself, $1700 \%$ Project: Mistaken for Muslim achieves its most profound intermedial critique of systemic racism in relation to the figurative dance act by Ok. As mentioned earlier, his performance physically translates the psychological threat to Muslim Americans into choreographed dance movements. Ok interprets these crimes in several shots when Ali, for instance, states, "[a] vehicle of white males, followed and harassed a $21 \mathrm{yr}$ old female. Attackers yelled: "Go back to your own country" (2:05-2:28). Here the dancer's abrupt movements intermedially cut into the nondiegetic voice-over.

Stylistically, it is important to note here that while many stanzas of the poem begin with the anaphoric "Awoke to...," which emphasizes the daily routine of waking up to hate-crime reports, the repeatedly used phrase "back up" from the situation above encapsulates a strategic device to counter ongoing racism against all ethnic minorities who potentially might be mistaken for being Muslim. As the presence of the volunteers makes clear as well, it affects Native Americans as much as Hispanic Americans, who are yelled at for "speaking Spanish at a doctor's office" (02:56-02:58). While vocally registering these incidences, Ali responds to this situation by exposing its absurdity through the use of irony. For instance, a scene when Ali recites the line "a man pushes a baby stroller" (02:44-02:46) evokes the notion of innocence. Yet, this notion is subverted when the same person uses the word "mosquito," an insect that is generally considered a blood-sucking nuisance, as a racist slur to condemn the presence of mosques in his neighborhood. The racist dimension of the incident gets even clearer when the father is "yelling, / You Islamic mosquitoes should be killed" (02:46-02:48), announcing a death-threat to the Muslim Americans. This act of racism is directly challenged, as Ali's now prison persona calls out the absurdity of the comparison, asking the viewer by way of an eye-level shot: "Mosquitoes mistaken for Muslims?" (02:52-02:54).

31 Another noteworthy strategy unfolds in an increasingly fast-paced vocal, musical, and visual rhythm, in which the cento poem achieves its full effect. The prisoner unleashes her critique of the absurdity of Othering people and even objects as follows:

Flags wave in an Afghan restaurant

300 march

against Spanish

spoken at a doctor's office

Spanish mistaken for Muslim

300 march

on two women

at a bagel store 
Bagels mistaken for Muslim

300 wave

cherry Bombs

march on 300 Sikhs

hitting a 3-year-old in the head.

LOOK!

what you people have done!

(0:35-0:59) Buddhist robe. Standing in solidarity with Muslim Americans (03:12ff.), she has regained her vitality just like the tree behind her that now has grown green leaves on previously bare branches. Directly facing the camera, she once more calls out the viewer stating: "Look what you people have done" (4:34-4:37). This statement can be read as an act of verbal opposition to the very foundations of the "Preamble" of The Constitution of the United States that famously states, "We the People." Ali's affront is met 
with a visual response. By way of a fade out, she is rendered conspicuously absent from the scene within a second, emphasizing the uncertain existence that ethnic Others are exposed to, who "refuse to end in violence" (4:52-4:57). Thus, through a range of discursive strategies and collective effort, $1700 \%$ Project: Mistaken for Muslim as a performance poetry clip serves as an appeal to end systemic and private Islamophobia in the United States.

\section{The Red Chador: Countering Islamophobia in National and Transnational Spaces}

37 In Anida Yoeu Ali's second performative engagement titled The Red Chador, the artist continues her creative fight against Islamophobia by responding to hate-crimes in a series of performances. As an activist piece, The Red Chador radically foregrounds Ali's gendered Muslim identity in national and transnational contexts. As mentioned in the opening section of this article, Islamic feminism has become a strategic form of identity politics in the United States, underscoring an important intersectional aspect in the fight against Islamophobia.

Ali first performed The Red Chador in Paris a few months after the attacks on Charlie Hebdo on November 13, 2015. At the time controversial public debates broke out in France about maintaining the Burqa ban first implemented in 2010 for an initially planned five years. As the photo below reveals, Ali's transnational border-crossing and the fact that she came to Paris for her art performance reflects what Nancy Fraser calls a "transnational politics of representation" (Fraser, Scales of Justice 100-101).

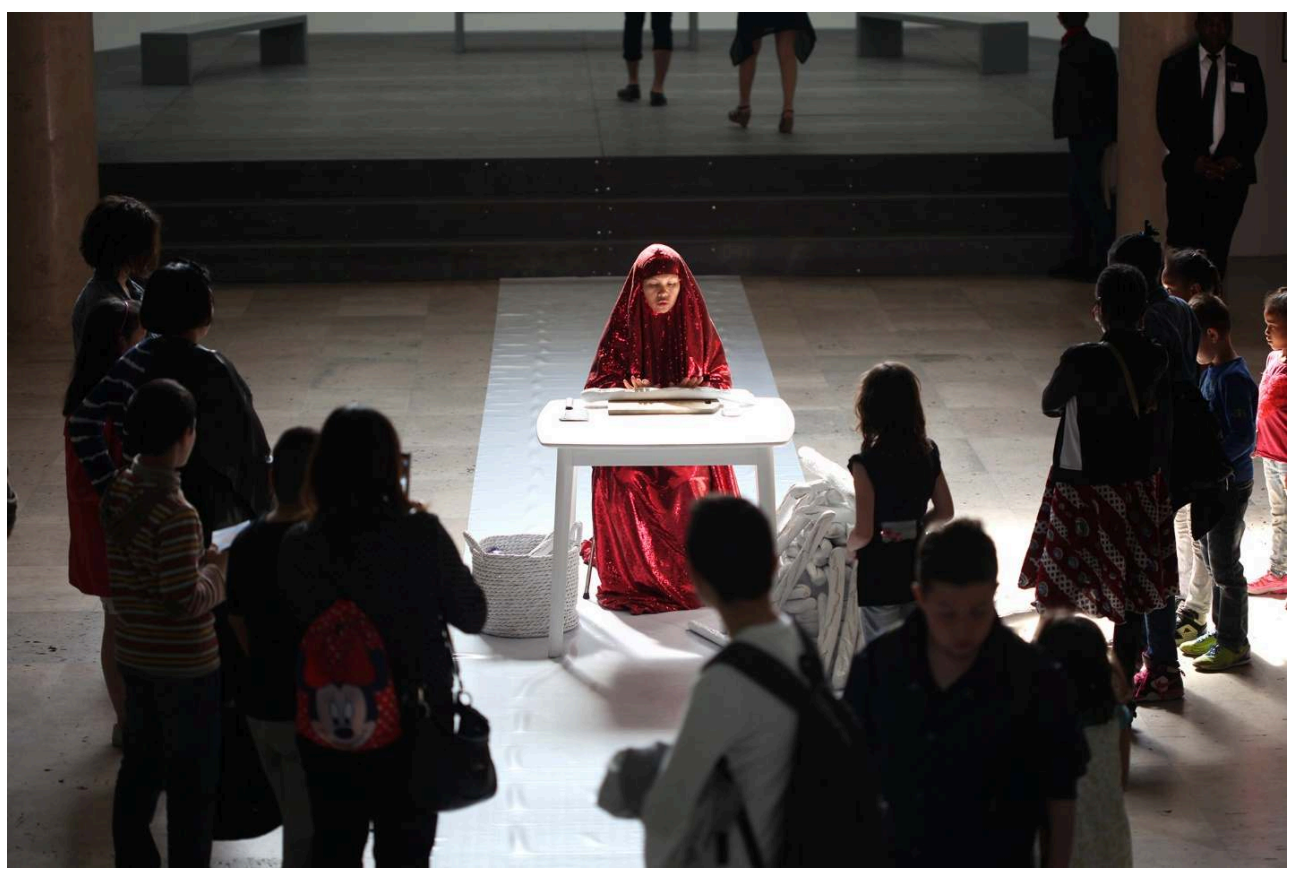

Figure 3. "Red Chador: Beheadings." Anida Yoeu Ali. Live performance at Palais de Tokyo; Paris, 2015. Photo courtesy of the artist; Photo Credit: Simon Martin.

Performing a reversal of power relations, "Red Chador: Beheadings" negotiates the decapitations of 99 French baguettes with a small but sharp meat ax. As part of her performance, she is making various claims on her audience in exchange for the safety 
of each baguette-symbolizing white supremacy-that she is capable of destroying. It also evokes France's colonial past that extends to Ali's country of birth, Cambodia. Thus, The Red Chador politicizes the moment. Dressed in a deep, blood-red burka, Ali's performance elicits images of the guillotine as a form of capital punishment in France from the eighteenth-century until as late as 1977. And, synchronously, the performance draws on what CNN broadcast journalist Jim Clancy referred to as "Syrian Savagery" and "barbarism" in July 2013. Thus, in The Red Chador, Ali is building on layers of associations that both agitate and provoke her audience as a female Muslim.

Among other performance events, The Red Chador was part of an exhibition on Memorial Day weekend at the Smithsonian Art and Industry building in Washington, D.C. in 2016 (Schlund-Vials 71). In "The Red Chador: Threshold," Ali challenged the audience's perception of Muslim Americans as unpatriotic, or even enemies of the state, asking on a printed boardsign: "Can we accept a Muslim woman as American?" Ali's feminist revolt is both engaging and upfront. As Beydoun states: "Although Muslim Americans are bona fide citizens, their religious identity induces scrutiny of their citizenship status, patriotism, and belonging" (119). This complicates the question of "constitutional patriotism" over "ethnic nationalism" (Fraser, Scales of Justice 135), provoking a response from the audience as to how they view her citizenship status within American society.

41 In fact, just one day after Trump's election on November 8, 2016, Anida Yoeu Ali took to the streets in Seattle wearing a completely veiled, sparkling full-body dress in a performance act titled "The Red Chador: The Day After."

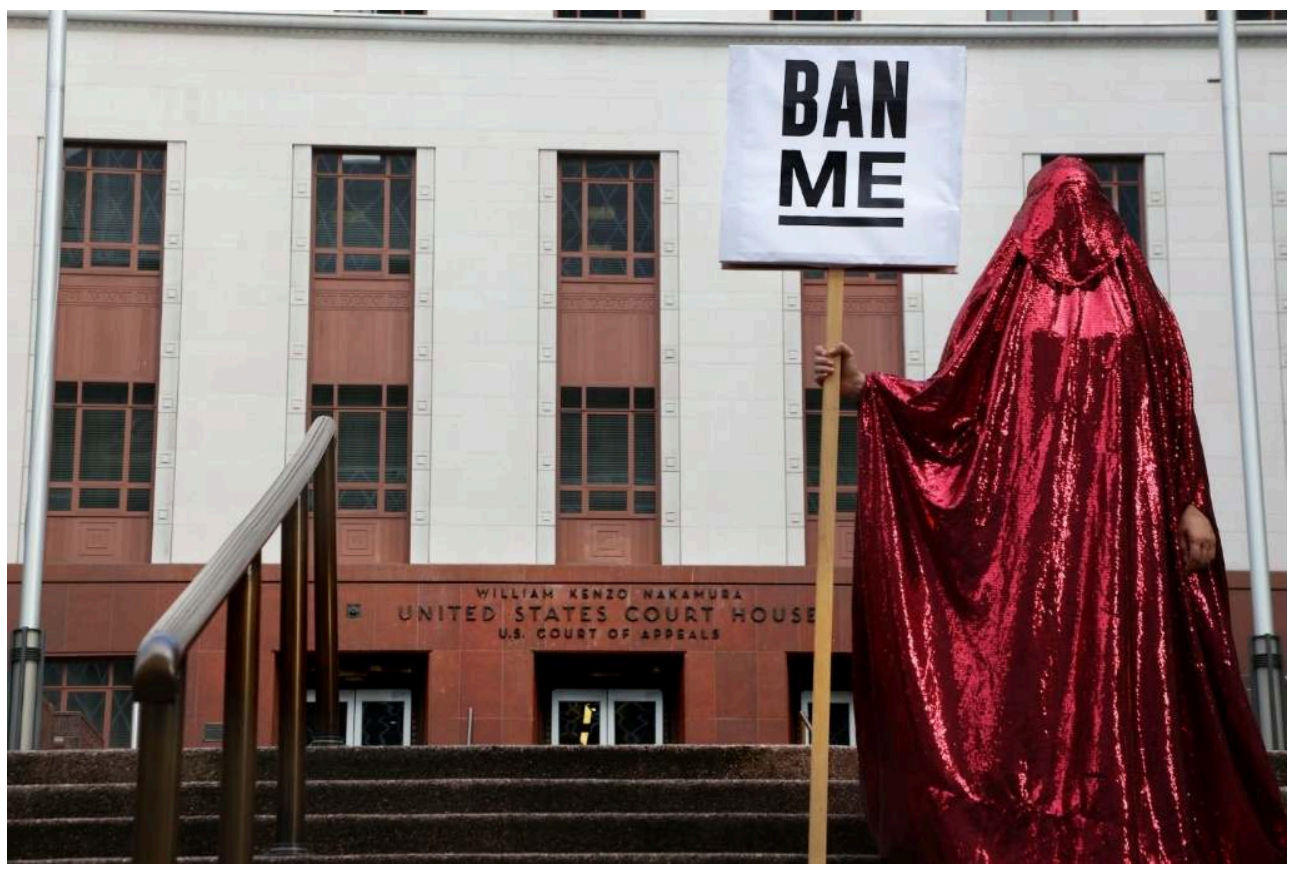

Figure 4. "Red Chador: The Day After." Anida Yoeu Ali Live performance US Courthouse; Seattle, 2016. Photo courtesy of the artist; Photo Credit: Masahiro Sugano.

The catchphrase "Ban Me" on her sign in the photo above is not merely a provocative statement against Islamophobia, which found its expression in Executive Order 13769 signed by Donald Trump on January 27, 2017, banning citizens from seven Muslimmajority countries (Iraq, Syria, Iran, Libya, Somalia, Sudan, and Yemen) from entering 
the US for a period of 90 days. As Beydoun puts it, the ban "was more than just a standalone policy that wrought mayhem in American airports, broke up families and ushered in a heightened form of structural Islamophobia.... The ban was part and parcel of a broader, stark Islamophobic vision that tied Muslim identity directly to terror suspicion" (176).

According to Rebecca Gould's essay "Punishing Violent Thoughts: Islamic Dissent and Thoreauvian Disobedience in Post-9/11 America": "it is only the latest in a long series of attempts to represent Islam as inherently alien to American culture" (2). The performance also uses the type of protest sign that has iconically been connected to the Civil Rights Movement.

Specifically, Ali's sign materially references and extends the Memphis Sanitation Workers Strike. As part of the famous protest that Martin Luther King participated in, African Americans held up signs stating: "I AM A MAN." Ali's sign reads "BAN ME" on the front and "I AM A MUSLIM" on the back. As Kaufer and Al-Malki put it, "[c]ounterpublics are materially embodied. They express themselves in the discourse and power relations of historical individuals and groups in particular locations and on a particular topic" (Kaufer and Al-Malki 50). Thus, the signal the performance sends is unmistakably one of civil justice for Muslims in general, and Muslim women in particular, who are frequently attacked in public spaces. In other words, not only does Ali align herself with a non-violent form of dissent and protest, but with her courageous performance she put herself on the spot as a Khmer American Muslim feminist.

By way of reframing her art and adapting it in new cultural contexts, including performances in Hong Kong and Kuala Lumpur in 2017, Ali demonstrates that Islamophobia does not stop at the state border. It is a transnational phenomenon that Muslim women, who wear hijabs or chadors, are even more likely to experience than Muslim men. In fact, following an exhibition as part of the $1^{\text {st }}$ Palestinian Performance Arts Network Conference in Ramallah in December 2017, the Red Chador was, according to Ali, lost. It disappeared, as the artist claims, in transit at Ben Gurion Airport, Tel Aviv, on her way home to the U.S. To mourn its loss, Ali created three memorial services (Ali, "The Red Chador Proposal Deck").

In May 2018, she streamed the event as part of the Asian Arts Initiative Celebration Weekend in Philadelphia, for which Ali prepared a eulogy, a digital altar, and a website titled redchadorisdead. The website asks visitors to leave comments, map their experiences, offer condolences, and provide eye-witness reports of past performances.

Using media convergence, the artist is reaching out to new audiences as an inherent part of her "agitational activities directed toward wider publics" (Fraser, Justice Interruptus 82) frequently "bypass[ing] state controls" (Fraser, Justice Interruptus 82). In short, the performance artist creates "transnational publics from which to mobilize international opinion" (Fraser, Justice Interruptus 82) against Islamophobic racism.

While the mourning for the loss of The Red Chador went on for more than one year, Ali began expanding herself into ever widening arenas. Most recently The Red Chador was rebirthed in Honololu, Hawaii. It reappeared on the Polynesian island in a variety of social contexts as part of Ali's artist residency at the Shangri La Museum of Islamic Art, Culture, and Design in Honololu in March 2020. Most strikingly, it not only came back 
as the same sparkling red dress: The Red Chador was accompanied by six women wearing the same sequin chador, each of them woven in another rainbow color:

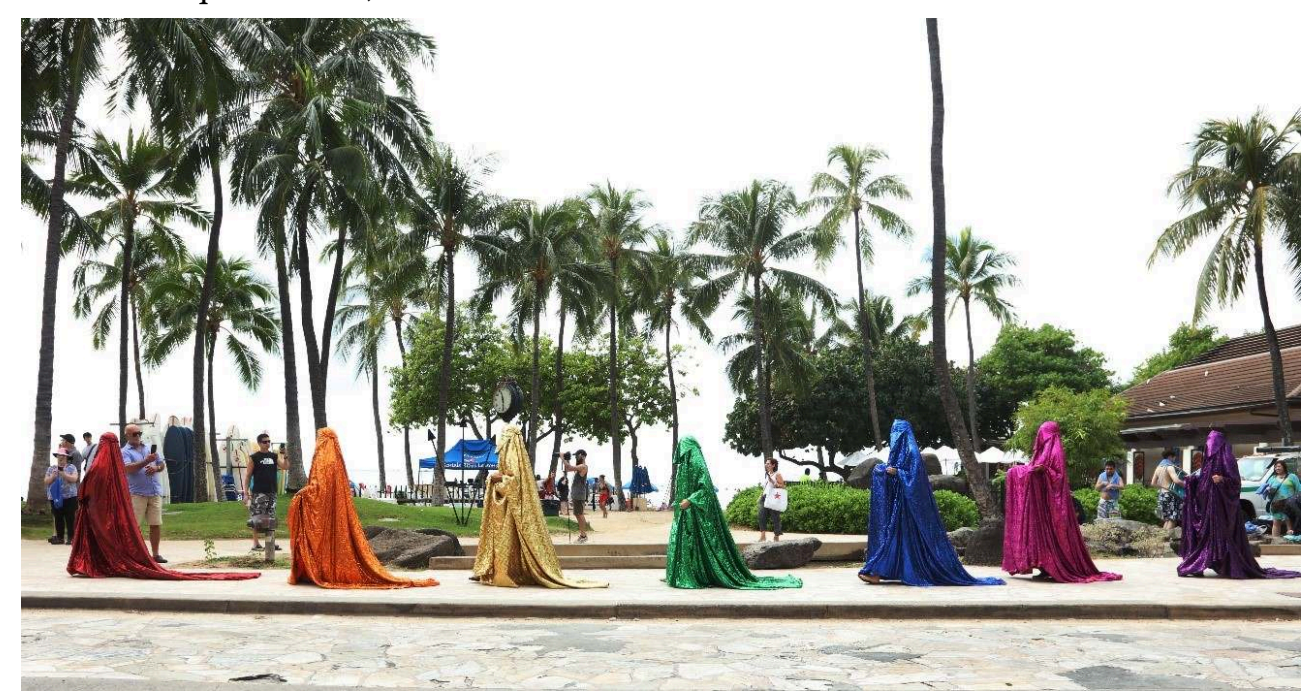

Figure 5. "Red Chador: Genesis I". Anida Yoeu Ali. Live performance at Waikiki Beach; Honolulu, 2019. Photo courtesy of the artist; Photo Credit: Masahiro Sugano.

As the image above signals, the collective appearance in a range of colors expresses a diversified and pluralistic image of Muslim women. As Ali explains her feminist goal: "to rebirth her [The Red Chador]... meant she had to come back to life in an epic way and that meant that she wasn't going to be alone" (01:05-01:14; emphasis added).

Not only does the rainbow draw on a long precolonial tradition of the Polynesian island as a "a pathway for celestial bodies to reappear" (01:24-01:27), but through this symbol she also aligns herself with Hawaii's legislative attempts to push back against the Muslim ban from 2017 (01:35-01:38). In view of a globally growing Black Lives Matter movement, the LGBTIQ+ movement, and most recently the Covid-19 pandemic health crisis, the symbol of the rainbow as a pluralistic and protective force is inextricably interwined with the artist's "transnational politics of representation" (Fraser, Scales of Justice 100-101).

\section{Conclusion}

Bringing back Jens Schröter's definitions of intermediality, Ali's performances not only thrive from synthetic intermediality as in "Red Chador: Beheadings" in the form of politicized art happening $s$ in museums. It is also partially present as transmedial intermediality in $1700 \%$ Project: Mistaken for Muslim, formally extending the cento tradition by using media convergence to fuel the poem's potential for resistance. And, Anida Yoeu Ali's work also reveals transformational intermediality in the interactive narrative mourning of the death of The Red Chador on the website redchadorisdead.com, which becomes and integral part of the morning process.

52 As Francisco J. Ricardo confirms in Literary Art in Digital Performance: "[w]hile human expressive force remains vibrant, electronic media have made it possible to create work that spans traditional distinctions at key junctures, to include the aesthetic and the poetic; the entirely participatory and the entirely receptive" (2). Finally, rather than 
using state media or private corporate media, Studio Revolt's independently produced art creates "subaltern counterpublics" (Fraser, "What's Critical" 81).

1700\% Project: Mistaken for Muslim uses multilayered media expressions, combining sound, spoken word poetry, dance, and film art to discursively counter Islamophobia. By arousing various "sensory modalities of interaction" (Jensen 1) in the viewer, the clip calls out hate crimes against Muslim Americans and those perceived as such to expose the dehumanizing function of ethnic Othering in the United States, in its past and present global repercussions. In this transnational context, The Red Chador reimagines the public sphere from a feminist Muslim American perspective, adding a transnational layer of participation and the creation of a counterpublic that intermedially extends its activist resistance from the street to the Internet. Creating visibility of Muslim women on a global scale, The Red Chador performances highlight the public sphere as both an empowering and vulnerable space for Muslim women in the twenty-first century. They invite a global audience to confront systemic racism and private Islamophobic acts of hate crimes against women who refuse to end in violence.

\section{BIBLIOGRAPHY}

1700\% Project: Mistaken for Muslim. Directed by Masahiro Sugano, with Anida Yoeu Ali. Accessed 5 August 2020. https://vimeo.com/11380785.

Abellan, Andrea. "Anida Yoeu Ali. You Can Have Very Powerful Conversations Without Speaking a Single Word.” Accessed 5 August 2020. https://www.salzburgglobal.org/news/latest-news/ article/anida-yoeu-ali-you-can-have-very-powerful-conversations-without-speaking-a-singleword.html.

Ali, Anida Yoeu. Artist Website. Accessed 5 August 2020. http://www.anidaali.com.

---. Accessed 5 August 2020. https://www.facebook.com/anida.ali.

---. 1700\% Project: Mistaken for Muslim. Accessed 5 August 2020. https://

1700percentproject.wordpress.com.

---. The Red Chador Is Dead. Accessed 5 August 2020. http://redchadorisdead.com.

---. "Red Chador. Proposal Deck". Unpublished pdf. provided by the artist in August 2020.

---. Bothell University, Bio. Accessed 5 August 2020. https://www.google.com/search?

client=firefox-b-d\&q=Bothell+Anida+Yoeu+Ali.

Ali, Anida Yoeu and Masahiro Sugano. Studio Revolt. Accessed 5 August 2020. http://studiorevolt.com.

Azam, Hina. "Islamic Feminism between Islam and Islamophobia." Journal of Middle East Women's Studies, vol. 14, no. 1, March 2018, pp. 124-128.

Beydoun, Khaled A. American Islamophobia: Understanding the Roots and Rise of Fear. U of California P, 2018. 
Cambodian Son. Directed by Masahiro Sugano, featuring Kosal Khiev, 2014. Accessed 5 August 2020. http://cambodianson.com.

Clancy, Jim. "Horrific Video Show Beheading in Syria." CNN, 3 July 2013. Accessed 5 August 2020. https://edition.cnn.com/videos/world/2013/07/03/clancy-syria-brutal-video.cnn.

Feldman, Keith P. “Anti-Muslim Racism beyond Islamophobia.” American Quarterly, vol. 71, no. 4, December 2019, pp. 1141-1153.

Fraser, Nancy. Scales of Justice: Reimagining Political Space in a Globalizing World. Columbia UP, 2008.

---. Justice Interruptus: Critical Reflections on the "Postsocialist" Condition. Routledge, 1997.

---. "What's Critical about Critical Theory?" Feminism as Critique, edited by Seyla Benhabib and Drucilla Cornell, U of Minnesota P, 1988, pp. 83-104.

Gombrich, F. Richard. Theravada Buddhism: A Social History from Ancient Benares to Modern Colombo. Routledge, 1988.

Gould, Rebecca Ruth. "Punishing Violent Thoughts: Islamic Dissent and Thoreauvian Disobedience in Post-9/11 America." American Journal of American Studies, 2018, pp. 1-26.

Hassan, Riffat. "The Development of Feminist Theology as a Means of Combating Injustice Towards Women in Muslim Communities/Culture." European Judaism, vol. 28, no 2, Autumn 1995, pp. 80-90.

Jamal, Amaney A. “Trump(ing) on Muslim Women: The Gendered Side of Islamophobia.” Journal of Middle Eastern Women's Studies, vol. 13, no. 3, November 2017, pp. 472-475.

Jenkins, Henry. “The Cultural Logic of Media Convergence.” Sage Journals, vol. 7, no. 1, 2004, pp. 33-43.

Jensen, Klaus Bruhn. "Intermediality." The International Encyclopedia of Communication Theory and Philosophy, Wiley-Blackwell, pp. 1-12.

Kaufer, David and Amal Mohammed Al-Malki. "The War on Terror through Arab-American Eyes: The Arab American Press as a Rhetorical Counter Public." Rhetoric Review, vol. 28, no. 1, 2009, pp. 47-65.

Mas, Ruth. “Transnational Politics: Recent Accounts of Muslims in France.” Journal of Middle East Women's Studies, vol. 6, no. 2, Spring 2010, pp. 123-132.

Ok, Prumsodon. The Serpent's Tail: A Brief History of Khmer Classical Dance. Accessed 5 August 2020. https://www.prumsodun.com.

---. The Magic of Classical Khmer Dance. TED TALK. Accessed 5 August 2020. https://www.ted.com/ talks/prumsodun_ok_the_magic_of_khmer_classical_dance.

Pfeiler, Martina. Poetry Goes Intermedia. U.S.-amerikanische Lyrik des 20. und 21. Jahrhunderts aus kultur- und medienwissenschaftlicher Perspektive. Francke Verlag, 2010.

Preminger, Alex and T.V.F. Brogan, editors. "Cento.” The New Princeton Encyclopedia of Poetry and Poetics, Princeton UP, 1993, p. 180.

Ricardo, Francisco J. Literary Art in Digital Performance: Case Studies in New Media Art and Criticism. Continuum, 2009.

Salaita, Steven George. "Beyond Orientalism and Islamophobia: 9/11, Anti-Arab Racism and the Mythos of National Pride.” The New Centennial Review, vol. 6, no 2, Fall 2006, pp. 245-266. 
Schlund-Vials, Cathy J. "Portfolio: Art, Activism and Agitations: Anida Yoeu Ali." Verge: Studies in Global Asias, vol. 3, no. 1, Spring 2017, pp. 54-75.

Schröter, Jens. "Das ur-intermediale Netzwerk und die (Neu-)Erfindung des Mediums im digitalen Modernism." Intermedialität. Analog/Digital, edited by Joachim Paech and Jens Schröter, FinkVerlag, 2008, pp. 579-602.

Shangri La Museum of Islamic Art, Culture \& Design. "Studio Revolt in Residence."Accessed on 10 August 2020. https://www.youtube.com/watch?v=TjH8r1jQCew\&fbclid.

Sovereign Asian Art Prize. Accessed on 5 August 2020. https://www.sovereignartfoundation.com.

Taylor, Keeanga-Yamahtta. "The White Power Presidency: Race and Class in the Trump Era." New Political Science, vol. 40, no. 1, March 2018, pp. 103-112.

Trump, Donald. "Donald Trump. Anderson Cooper Interview. Part Two." CNN, 3 March 2016. Accessed 5 August 2020. https://www.youtube.com/watch?v=im_uLJKzs-4.

Van Veeren, Elspeth. “Orange Prison Jumpsuit.” Making Things International 2: Catalysts and Reactions, edited by Mark B. Salter, U of Minnesota P, 2016, pp. 122-136.

\section{ABSTRACTS}

This article investigates Anida Yoeu Ali's performance art as that of a Muslim, Khmer-American feminist global agitator, who challenges Islamophobia in the United States and transnationally by expanding her work "into ever-widening arenas" (Fraser, Justice Interruptus 82). Her performance projects formulate oppositional interpretations of Muslim "identities, interests, and needs" (Fraser, Justice Interruptus 82) in an increasingly Islamophobic era from the aftermath of 9/11 to Donald Trump's presidency. Drawing on theories of convergence culture and intermediality, this article provides a close analysis of Ali's performance projects. The first work is titled $1700 \%$ Project: Mistaken for Muslim (2010), a performance poetry clip that was directed by the Japanese American filmmaker Masahiro Sugano in 2010 and which widely circulates on the Internet. It stands out as a feminist, transnational critique of an unprecedented "undermining [of] Muslim voices" (Azam 125). The article also includes an exploration of a selection of performance acts from Ali's The Red Chador Series $(2015 ; 2018 ; 2020)$. I argue that by establishing discursive counternarratives the two works highlight the cultural potential of using intermediality to challenge private and public Islamophobia in a globally connected world. Thus, these works will be explored as a performative engagement with national, transnational, and gendered dimensions of Islamophobia.

\section{INDEX}

Keywords: Islamophobia, intermediality, performance art, hate crimes, Muslim feminism

\section{AUTHOR}

\section{MARTINA PFEILER}

Martina Pfeiler currently acts as interim chair of American Studies (Kommissarische Lehrstuhlvertretung) at Ruhr-University Bochum. In her research and teaching she focuses on the cultural intersections and creative border crossings of $19^{\text {th }}$ to $21^{\text {st }}$ centuries U.S.-American 
literature, film, and digital media. In 2017 she completed her Habilitation at TU Dortmund University with a thesis titled Ahab in Love: The Creative Reception of Moby-Dick in Popular Culture. Results of this research have appeared in Leviathan. A Journal of Melville Studies, Literature/Film Quarterly, and are forthcoming in A Companion to Herman Melville in 2021. She is also the author of Poetry Goes Intermedia: U.S.-amerikanische Lyrik des 20. und 21. Jahrhunderts aus kultur- und medienwissenschaftlicher Perspektive (2010) and Sounds of Poetry: Contemporary American Performance Poets (2003). 